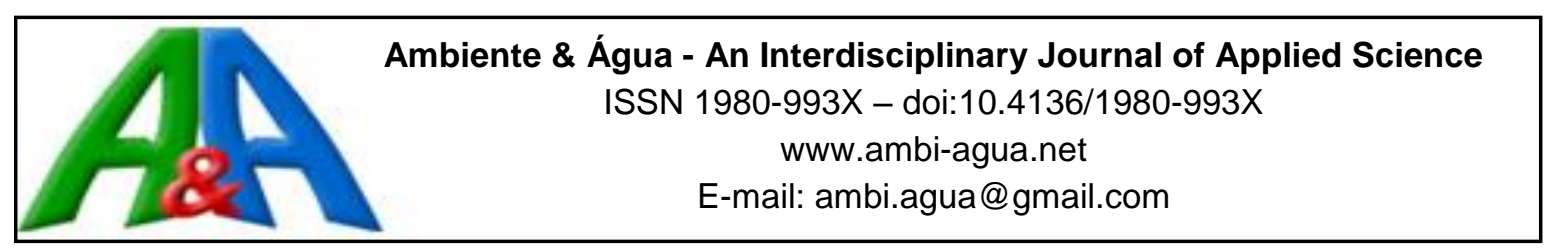

\title{
Constructed wetlands as post treatment of a decanter digester followed by an anaerobic filter
}

\author{
ARTICLES doi:10.4136/ambi-agua.2335
}

Received: 01 Oct. 2018; Accepted: 11 Jun. 2019

\author{
Wilhan Douglas Reis*iD; Aldecy de Almeida Santos ${ }^{*}$;

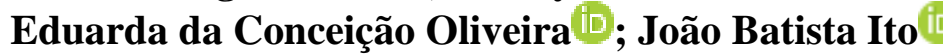 \\ Universidade Federal de Mato Grosso (UFMT), Cuiabá, MT, Brasil \\ Programa de Pós-Graduação de Recursos Hídricos (PPGRH). \\ E-mail: wilhan_cba@hotmail.com, aldecy_allmeida@yahoo.com.br, \\ eduarda.ambiental@gmail.com,jbbito2@yahoo.com.br \\ *Corresponding author
}

\begin{abstract}
The amount of wastewater has increased due to the considerable expansion of higher education institutions. When wastewater is released without treatment or with inefficient treatment, it causes significant water pollution. In this context, this study evaluated the performance of Constructed Wetlands as a post-treatment of a decanter digester followed by an anaerobic filter, operated with effluent from the Federal University of Mato Grosso, Cuiabá Campus, Mato Grosso State. Four wetlands were constructed to develop the research: planted with Typha domingensis, planted with Heliconia psittacorum, planted with Pontederia parviflora, and not planted. The following physicochemical parameters were analyzed: Color, Turbidity, pH, Temperature, Total Solids, Total Dissolved Solids (TDS), Biochemical Oxygen Demand (BOD), Chemical Oxygen Demand (COD), Total Nitrogen, Sulfate, Nitrate and Nitrite. The results show an organic matter removal efficiency with mean removal results: $70 \%$ $\mathrm{BOD}_{5}$ for $\mathrm{TCW}, \mathrm{HCW}$ and $\mathrm{PCW}$; and $\mathrm{COD} 76 \%$ for $\mathrm{PCW}$. The mean removal of total phosphorus was $78 \%$ for $\mathrm{PCW}$ and $92 \% \mathrm{NO}^{-2}$, as macronutrients. Analysis of variance ANOVA shows significance in the results of $\mathrm{TDS}, \mathrm{SO}_{4}$ and $\mathrm{COD}$ removal.
\end{abstract}

Keywords: biotechnology, horizontal subsurface flow, macrophytes, wastewater.

\section{Wetlands construídos como pós-tratamento de um decanto-digestor seguido de um filtro anaeróbio}

\section{RESUMO}

Com a crescente expansão das Instituições de Ensino Superior (IES), aumentam-se a quantidade de águas residuais, quando a mesma é lançada sem tratamento ou com tratamento ineficiente contribuem de maneira significativa para poluição dos recursos hídricos. Neste contexto, o objetivo deste trabalho foi avaliar o desempenho de Wetlands Construídos (WC) como pós-tratamento de decanto-digestor seguido de filtro anaeróbio, operados com efluente da Universidade Federal de Mato Grosso Campus Cuiabá-MT, no que se refere à remoção de nutrientes e matérias orgânicas. Para o desenvolvimento da pesquisa foram construídos quatro wetlands, sendo eles: WCT - plantado com Typha domingensis, WCH - plantado com Heliconia psittacorum, WCP plantado com Pontederia Parviflora, e WCB - não plantado. Foram 
analisados os parâmetros físico-químicos de cor, turbidez, $\mathrm{pH}$, temperatura, Sólidos Totais (ST), Sólidos Totais Dissolvidos (STD), Demanda Bioquímica de Oxigênio (DBO $)_{5}$, Demanda Química de Oxigênio (DQO), nitrogênio total, fósforo, sulfato, nitrato e nitrito. Os resultados obtidos mostram uma eficiência de remoção de matéria orgânica com resultados médios de remoção: de $\mathrm{DBO}_{5} 70 \%$ para WCT, WCH e WCP; e de DQO $76 \%$ para WCP. A remoção média de fósforo total $78 \%$ para WCP e $\mathrm{NO}^{-2} 92 \%$, como macronutrientes. A análise de variância ANOVA mostra significância nos resultados de remoção de STD, $\mathrm{SO}_{4}$ e DQO.

Palavras-chave: águas residuais, fitorremediação, fluxo horizontal subsuperficial, macrófitas.

\section{INTRODUCTION}

Wastewater from universities (WU) contains pollutant loads that, if discarded without treatment, can degrade water resources. This occurs when the pollutants are in contact with different processes of water use at universities, leading to water contamination, and thus changing chemical, physical and biological patterns (Santín et al., 2016; Freitas et al., 2016).

Wastewater treatment plants (WTPs) are responsible for restoring water quality standards to return it as naturally as possible to watercourses (Meneses et al., 2015). In order to reduce impacts caused to the environment by sanitary sewage at universities, the water goes through wastewater treatment procedures in WTPs that can efficiently remove the dissolved particles, suspended and organic loads that are added to the wastewater (Morrison et al., 2016; Wagner and Da Costa, 2015).

The Federal University of Mato Grosso is located in the Barbado Stream Basin in the city of Cuiabá, Mato Grosso state, a tributary of the Cuiabá River, and has a decanter digester as wastewater treatment, which comprises wastewater storage tanks. These tanks have active sludge inside with bacterial colonies capable of degrading organic matter through anaerobic biological processes such as hydrolysis, acidogenesis, acetogenesis, methanogenesis and sulfidogenesis. This wastewater treatment system, although simple and cheap, is inefficient in terms of organic matter removal (Chernicharo, 2019).

The aim of a Constructed Wetland $(\mathrm{CW})$ is to treat both raw and post-treatment wastewater, thus ensuring greater efficiency in the removal of organic fats and macronutrients. A CW can operate in two ways: with the flow free flow where the macrophytes are floating or emerging (Toscano et al., 2015); or with subsurface flow (Rodríguez and Brisson, 2015).

CWs are commonly used in countries such as Chile, Spain and Canada (Vera et al., 2013, Casas-Ledón et al., 2017, Caselles-Osorio et al., 2017), mainly in post-treatment, because they have plants that have the capacity to absorb macronutrients $(\mathrm{N}$ and $\mathrm{P})$, which are released in the process of decomposing matter, as well as in the nitrification process that occurs in bacteria related to the roots of plants (according to Li et al., 2015).

This study evaluated the efficiency of a $\mathrm{CW}$ as post-treatment of a decanter digester followed by an anaerobic filter on an experimental scale.

\section{MATERIAL AND METHODS}

The methodology was developed in three stages: I) designing and constructing the experiment in a pilot scale of the CW; II) monitoring the physico-chemical parameters of the WTP; and III) monitoring the physicochemical parameters and CW biomass growth.

The experiment was carried out at the WTP at the Federal University of Mato Grosso, Cuiabá Campus, located between the geographic coordinates $21 \mathrm{~S} 600022.00 \mathrm{~m} \mathrm{E}$ and $8274119.00 \mathrm{~m} \mathrm{~S}$. The climate in the city of Cuiabá is characterized as continental tropical, with two distinct seasonal seasons, one rainy (October-March) and the other dry (April-September). It has an annual precipitation of $1.262 \mathrm{~mm}$ and an average temperature of $25,91^{\circ} \mathrm{C}$ (INMET, 2018).

Rev. Ambient. Água vol. 14 n. 4, e2335 - Taubaté 2019 
The wastewater treatment system is formed by a lift station that receives the WU, from the sanitary station of the university, and from the Jardim América neighborhood. It is then pumped to the WTP, which is comprised of a Decanter Digestor, where the degradation of organic matter occurs anaerobically. This is followed by a biofilter, which retains part of the dissolved solids of the system, and then finally the Drying Bed (DB).

The treated effluent from the WTP was moved by a peristaltic pump to a reservoir of $1 \mathrm{~m}^{3}$ made of polyethylene, then by gravity to $\mathrm{CWs}$, which were fed continuously in a subsurface form with controlled flows in each $\mathrm{CW}$, at a flow rate of 50 liters / 10 days. The internal volume of the tanks used in the $\mathrm{CW}$ implantation was $0.45 \mathrm{~m}^{3}$, made of high-density polyethylene, with a surface length of $2.20 \mathrm{~m}$ and a depth of $1.84 \mathrm{~m}$, a surface width of $0.71 \mathrm{~m}$, and a bottom measuring $0.33 \mathrm{~m}$, respectively. The substrate filling consisted of a sequence of filter layers: hand stone, washed sand and gravel $\mathrm{N}^{\circ} .02$.

Four wetlands were constructed, with three different species of macrophytes in separate planted CWs and one unplanted CW; those that were planted had a density of 10 rhizomes per CW, divided into the following: one was planted with Typha domingensis (TCW), one planted with Heliconia psittacorum (HCW), one planted with Pontederia Parviflora (PCW), and one was not planted (NCW) in order to obtain the block of the treatment tanks (Figure 1).
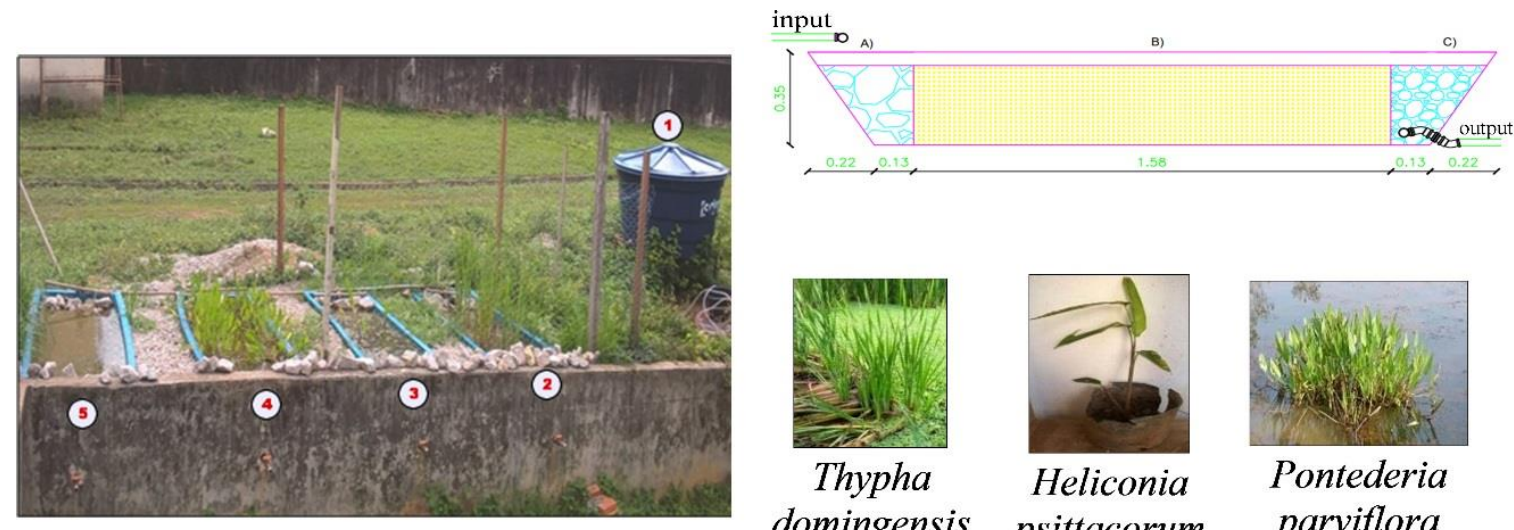

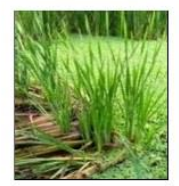

Thypha

domingensis

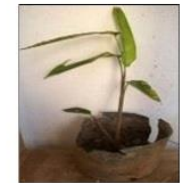

Heliconia

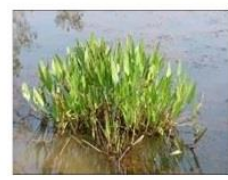

Pontederia parviflora

1Reservoir; $2 \mathrm{CW}$ planted with Thypha; $3 \mathrm{CW}$ planted with Heliconia; $4 \mathrm{CW}$ with Pontederia; and $5 \mathrm{CW}$ not planted. A) stone hand; $\mathrm{B}$ ) sand; C) gravel $\mathrm{N}^{\circ} 2$

Figure 1. Constructed Wetland.

Sampling was carried out from October 2017 to February 2018, and six points were monitored at the WTP: Gross Effluent - Point 1 (P1) - Landfill and Treated Effluent - Point 2 (P2) - Biofilter Output, considering the flow of the system structure. The other four samples at the output of each CW, occurring over a period of 150 days, complied with the Hydraulic Detention Time (HDT) of 5 and 10 days. The samples were collected using collector tubes installed in each CW tank at the following sampling points: TCW, HCW, PCW and NCW.

Samples were analyzed considering the following parameters: Total Dissolved Solids TDS (mg /l), Total Phosphorus - TP (mg/l), Sulphate - $\mathrm{SO}_{4}(\mathrm{mg} / \mathrm{l})$, Nitrate $-\mathrm{NO}^{-3}(\mathrm{mg} / \mathrm{l})$, Nitrite - $\mathrm{NO}^{-2}(\mathrm{mg} / \mathrm{l})$, Total Nitrogen - TN (mg/l), pH, Biochemical Oxygen Demand - BOD 5 (mg/l) and Chemical Oxygen Demand - COD (mg/l).

After collecting the concentration results of the TDS, TP, $\mathrm{SO}_{4}, \mathrm{NO}^{-3}, \mathrm{NT}, \mathrm{NO}^{-2}, \mathrm{BOD}_{5}$ and COD parameters, they were submitted to Equation 1 to each $\mathrm{CW}$ to obtain the Removal Efficiency.

$$
R E=\frac{\operatorname{Conc}(P 2)-\operatorname{Conc}(C W)}{\operatorname{Conc}(P 2)} \times 100
$$

At where:

$\underline{\text { Conc }(\mathrm{CW}) \neq 0}$ 


\subsection{Biomass}

Every 10 days, four plants from each treatment were collected and separated into roots, leaves and stems. Afterwards, the roots were washed in running water and distilled to remove soil. The vegetal material was placed individually in paper bags, properly identified and then dried in a forced ventilation oven at $70^{\circ} \mathrm{C}$ for 48 hours. Finally, the material was weighed to calculate the dry mass of the leaves, roots and stems of each plant.

Statistical analyses of the results from the laboratory analyses were performed by the paired ANOVA test that evaluated the variance of the results, as well as the standard deviation between them. Significant differences in water quality between wet and dry plant species were evaluated using a completely randomized analysis of variance with significance of 5\% and $10 \%$. To prove the variance test, the correlation test was used to determine the relationship between the parameters.

\section{RESULTS AND DISCUSSION}

Dissolved Oxygen inside the WTP and CW varied between 0.91 and 7.24; the WTP output was lower than the standards established by CONAMA (Brazilian National Council for the Environment) due to the anaerobic system where the $\mathrm{pH}$ rises and DO decreases (Figure 2). The CWs had a higher oxygen insertion at the beginning of the experiment, decreasing after the month of January. This variation is related to plant respiration and biofilm development using DO in the decomposition of organic matter (Pelissari et al., 2014).

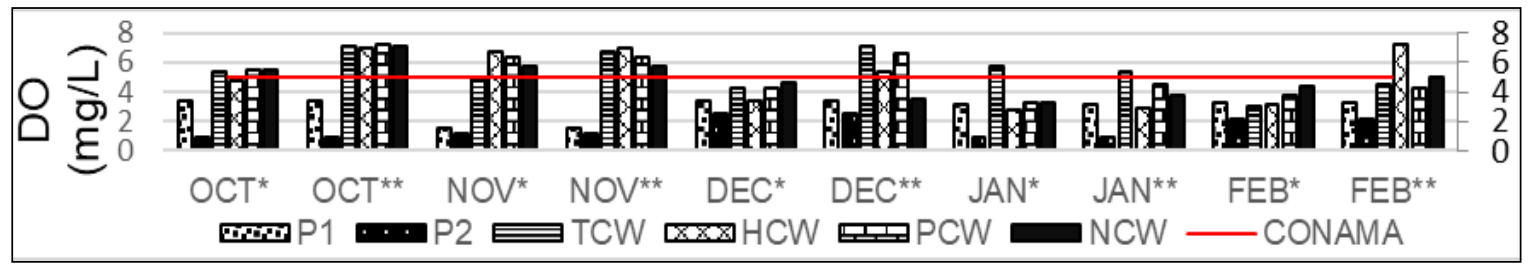

Figure 2. Dissolved Oxygen Variation.

The results of $\mathrm{pH}$ and $\mathrm{CW}$ in the WTP varied between 8.95 and 6.81, within the range established by CONAMA (Figure 3), and the most alkaline result was recorded in the HCW in the HDT on October 10th, and the most acidic result was recorded in the TCW in the HDT also on October $10^{\text {th }}$. These values correspond to those of Caselles-Osorio (2017), who states that plant root growth can influence plant $\mathrm{pH}$ by acidifying the medium with carbon production due to respiration (Kadlec et al., 1996; Vymazal, 2007).

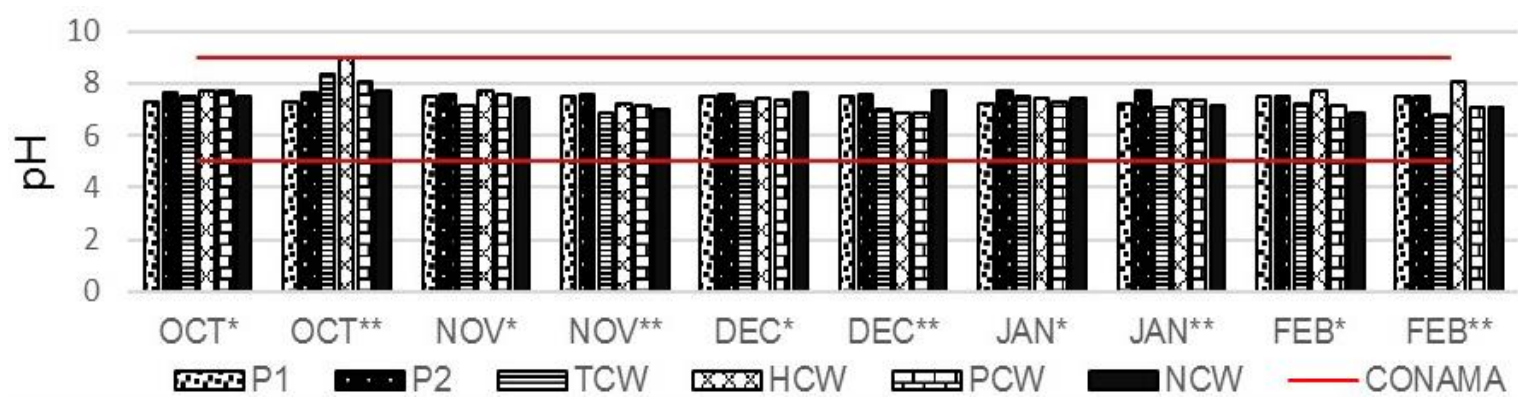

Figure 3. $\mathrm{pH}$ variation.

The CW removals were calculated in relation to $\mathrm{P} 1$ following the research sample; therefore, the average removal efficiency of the TDS in the HDT of 5 days was highlighted by the PCW, with 51\%. The others had close values, which were $48 \%, 50 \%$ and $46 \%$ for TCW, $\mathrm{HCW}$ and NCW, respectively. In the 10-day results, the efficiencies of all CWs rose. The PCW

Rev. Ambient. Água vol. 14 n. 4, e2335 - Taubaté 2019 
had the best result, with a value of $73 \%$, while the other TCW, HCW, NCW obtained $71 \%$, $72 \%$ and $61 \%$, respectively. These values show that there was increased efficiency in the TDS, similar to those of Sehar et al., who obtained efficiency values between $42 \%$ and $74 \%$, in their experiment at a 20-day TDH. In the present study, it was observed that the removal of TS is related to sorption in the filter medium, absorption by the plants (Figure 4) (Sezerino et al., 2015).
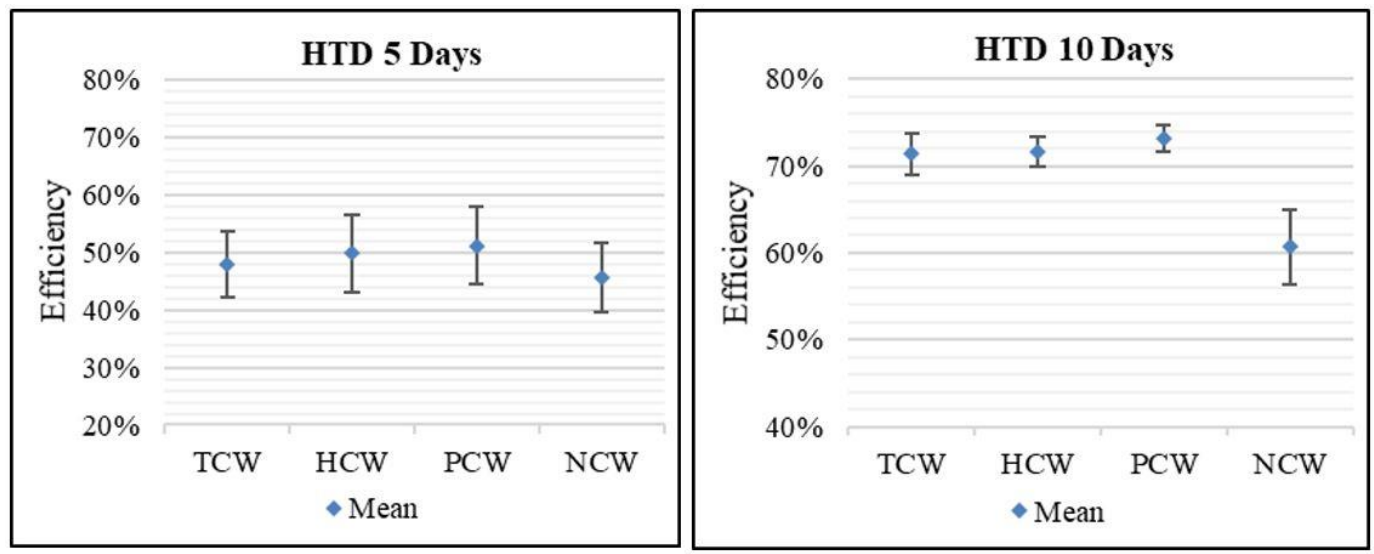

Figure 4. Total Dissolved Solids efficiency.

Phosphorus in the CW had a great variation mainly in the months of November 2017 and February 2017, but the CW behaved efficiently in both concentrations. The average phosphorus efficiencies in the HDT of 10 days were $49 \%, 45 \%, 78 \%$ and $41 \%$, for TCW, HCW, PCWP and NCW, respectively.

The $\mathrm{P}$ is part of the macronutrients that the plants absorb to use in their metabolic compositions, comparing the phosphorus concentrations with Abou-Elela and Hellal (2012) and Leto et al. (2013) who obtained a result of $62 \%$ removal and $47.9 \%$ with a concentration of $0.4 \mathrm{mg} / \mathrm{l}$ and $4.2 \mathrm{mg} / \mathrm{l}$. The PCW obtained better removal results, while TCW, HCW and NCW obtained results of efficiency lower than both (Figure 5).

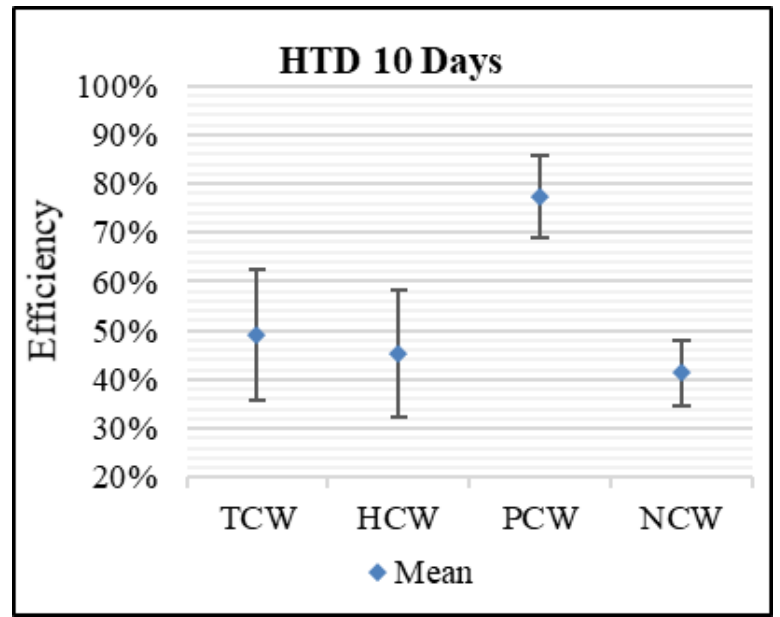

Figure 5. Phosphorus efficiency.

The mean sulphate efficiencies in 5 days of HDT were $60 \%, 59 \%, 65 \%$ and $35 \%$ for TCW, HCW, PCW and NCW, respectively; and in 10 days of HDT were 95\%, 99\%, 95\% and 93\% for TCW, HCW, PCW and NCW, respectively. These results show that in the planted CWs, there was higher sulphate removal efficiency compared to the non-planted ones. This may be related to oxygen in the available plant roots (Figure 6).

\section{IPABH}

Rev. Ambient. Água vol. 14 n. 4, e2335 - Taubaté 2019 

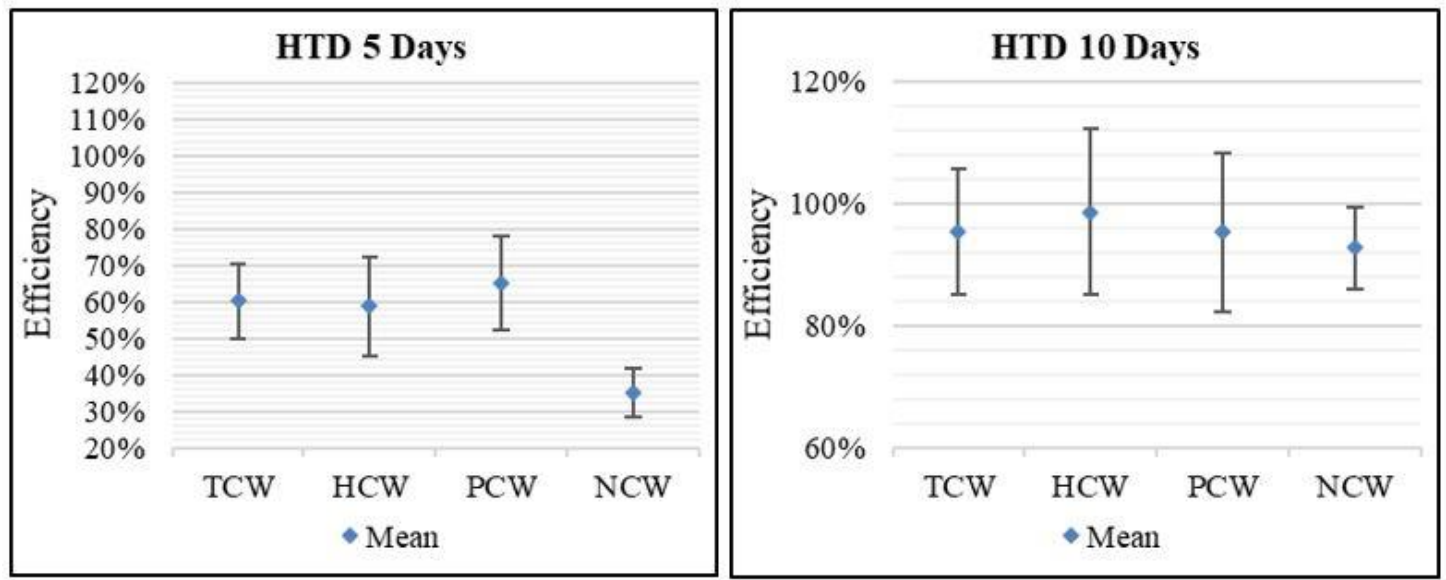

Figure 6. Sulphate efficiency.

The mean efficiency of $\mathrm{NO}^{-2}$ in the HDT of 5 days was: $68 \%, 57 \%, 61 \%$ and $66 \%$ for TCW, HCW, PCW and NCW, respectively; for 10 days, it was $92 \%, 88 \%, 89 \%$ and $78 \%$, for TCW, HCW, PCW and NCW, respectively. The mean $\mathrm{NO}^{-3}$ removal in the HDT of 5 days was $66 \%, 66 \%, 67 \%$ and $57 \%$ for TCW, HCW, PCW and NCW, respectively; for 10 days it was $86 \%, 75 \%, 82 \%$ and 67 for TCW, HCW, PCW and NCW, respectively. The removal of $\mathrm{NO}^{-3}$ and $\mathrm{NO}^{-2}$ occurs due to the absorption of nutrients by plants and the release of oxygen forming $\mathrm{N}_{2}$ (Sehar et al., 2014). Maine et al. (2006) obtained results of $88 \%$ and $85 \%$ concerning the removal of $\mathrm{NO}^{-3}$ and $\mathrm{NO}^{-2}$, in WC planted with Typha domingensis and Panicum elephantipes (Figure 7).

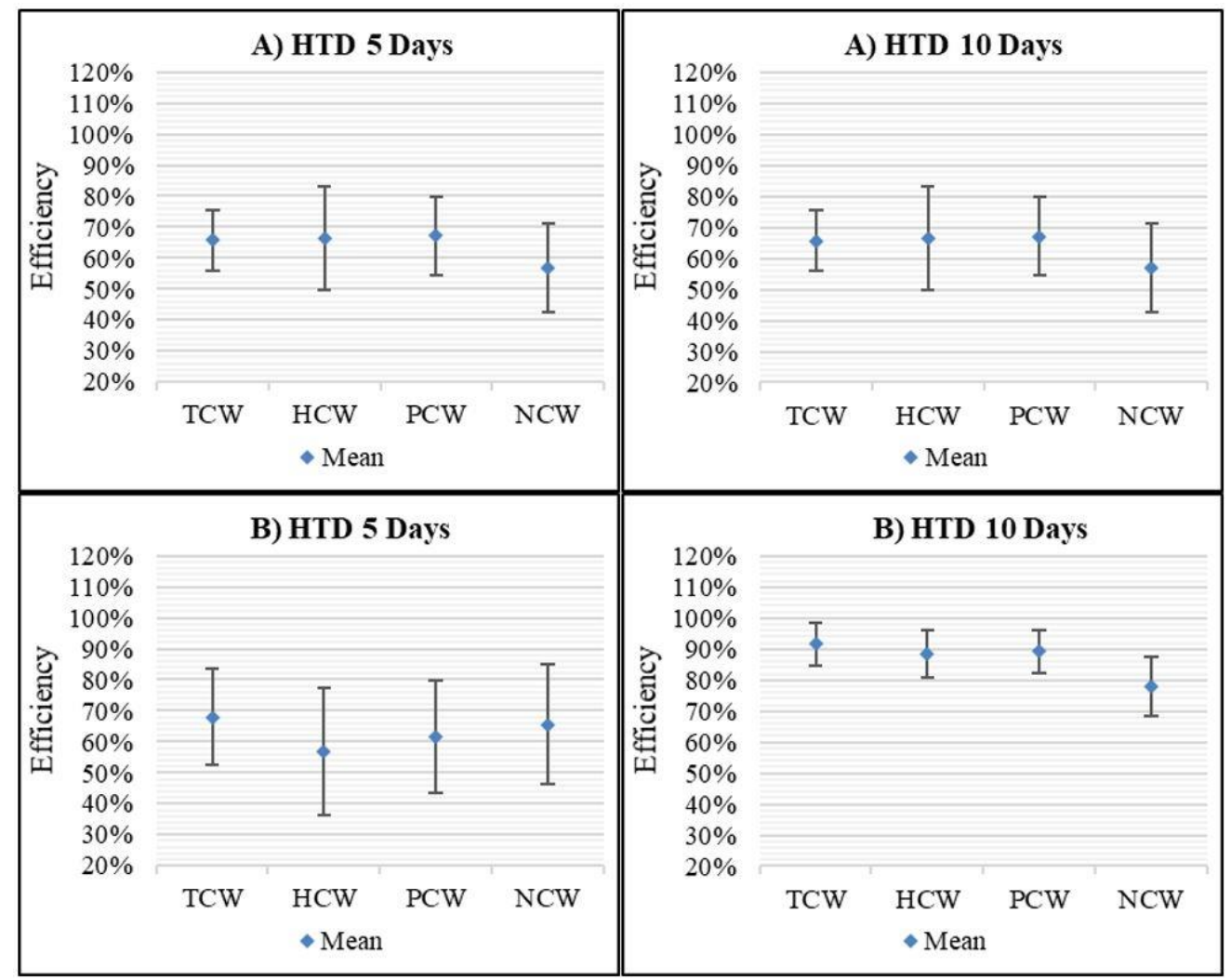

Figure 7. Efficiency of Nitrite and Nitrate.

The mean total nitrogen efficiency results in the HDT of 10 days were $52 \%, 42 \%, 34 \%$ and $31 \%$, for TCW, HCW, PCW and NCW, respectively. The maximum removal in the PCW 
was the one that stood out, as it had $60 \%$ in October 2017. Hsu et al. (2011) obtained a result of Total Nitrogen removal in a natural wetland which is close to the results of the present study. However, in an experiment similar to this one, Rodríguez and Brisson (2015) managed a removal of $97 \%$ (Figure 8 ).

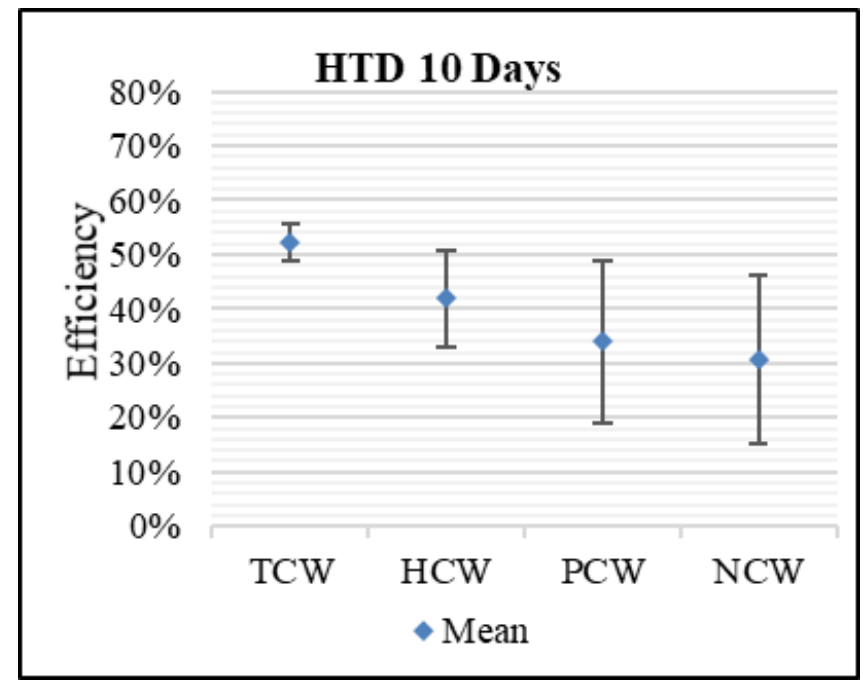

Figure 8. Total Nitrogen Removal.

The BOD 5 obtained the mean efficiency for the HDT of 5 days, which was less than $50 \%$. The CW that had the best mean efficiency was HCW with $45 \%$, then PCW with $44 \%$, TCW with $42 \%$ and NCW with $38 \%$. However, the results of the 10-day analysis were the same for all planted CWs at 70\%, and the NCW was 66\%. The 5-day and 10-day HDT efficiency values, despite being effective in maintaining lower load effluent within the limits of CONAMA 357/05, these same results in the HDT of 5 days are lower than those of Sohsalam et al. (2008); Vera et al. (2013) and Abou-Elela and Hellal (2012); and the efficiency result in the HDT of 10 days are equal to these authors. $\mathrm{BOD}_{5}$ removal occurs due to deposition and filtration, while organic compounds were degraded aerobically and anaerobically by heterotrophic microorganisms, depending on the concentration of oxygen in the bed (Figure 9).
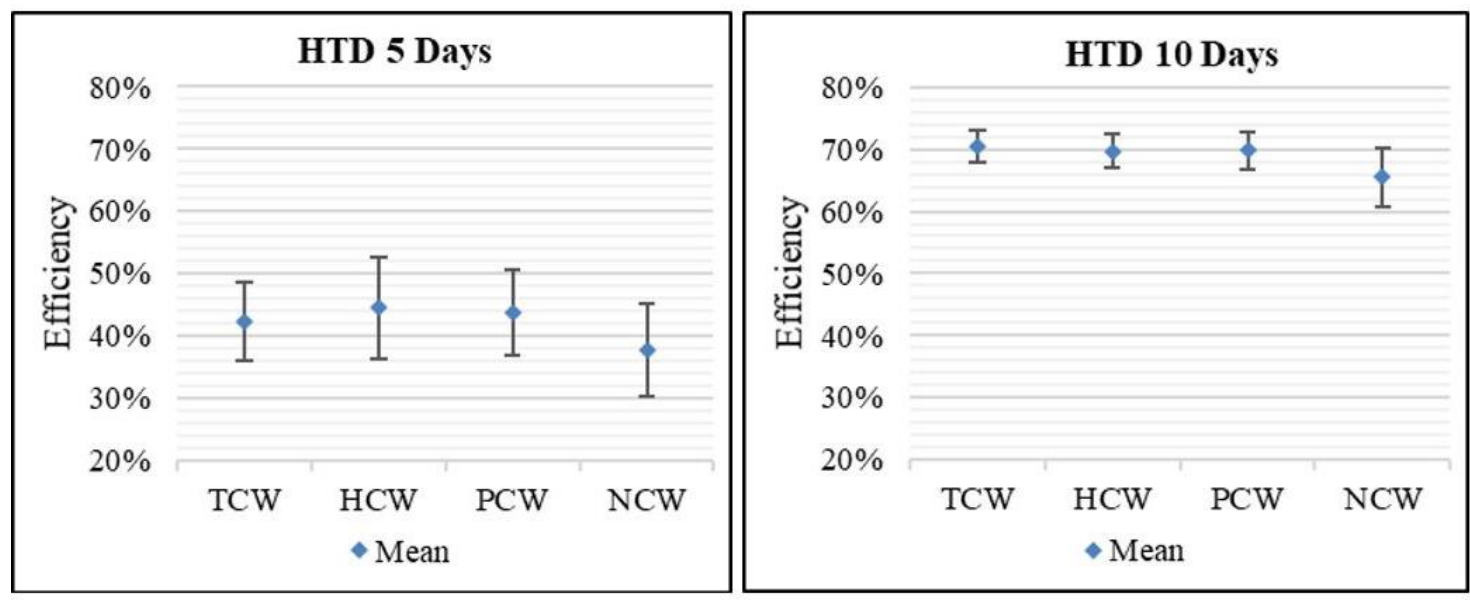

Figure 9. $\mathrm{BOD}_{5}$ efficiency.

The mean COD removals for TCW, HCW, PCW and NCW were $42 \%, 34 \%, 47 \%$ and $29 \%$, respectively, in the HDT of 5 days. In the HDT of 10 days, the values were close, ranging from $76 \%$ to $69 \%$. The COD values were similar to those of Ansola et al. (2003), Caselles-Osorio et al. (2011) and Ebrahimi et al. (2013), who had mean values of efficiency of 79\%, 75\% and 
$72 \%$. These studies found a greater efficiency in planted CWs due to the assimilation of the plant to organic materials and macro nutrients found in the wastewater (Figure 10).
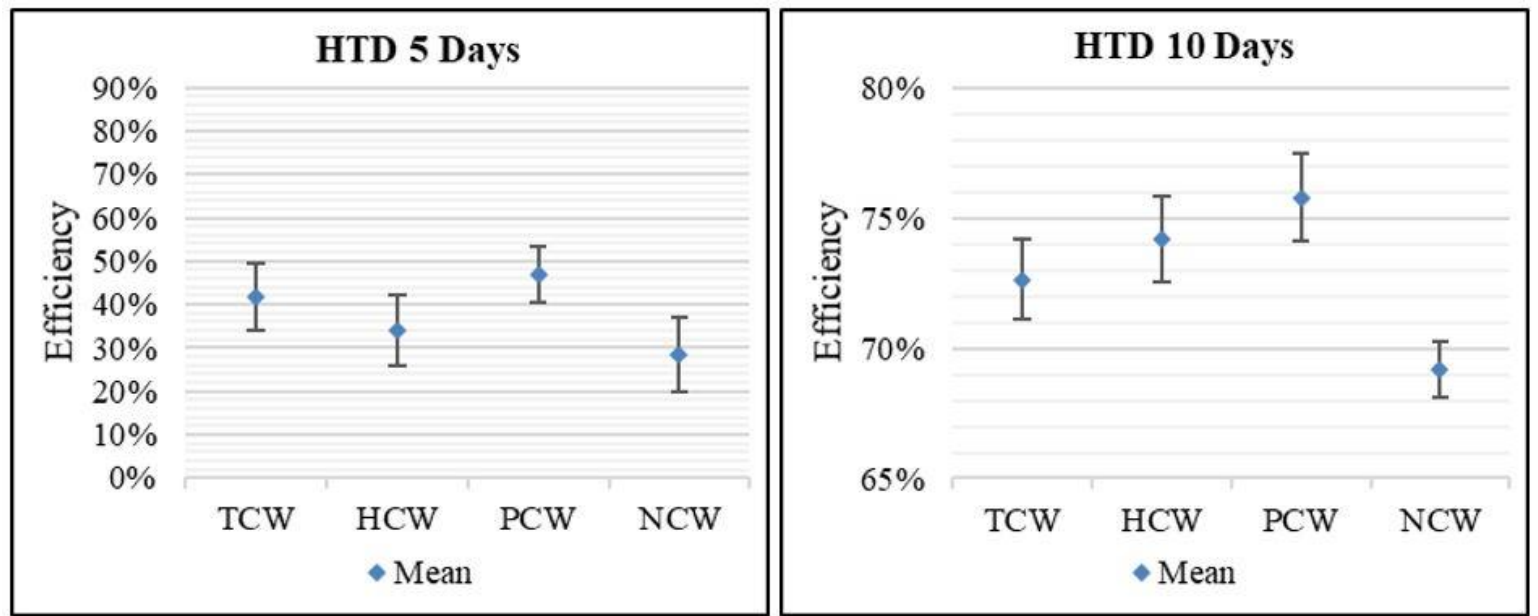

Figure 10. COD efficiency.

\subsection{Development of macrophytes}

The macrophytes were planted in their young stage and accompanied by their growth in height $(\mathrm{cm})$ and weight $(\mathrm{g})$. The result shows the growth variation between plants from the young to the adult stages. Among the macrophytes, Typha domingensis and Pontederia parviflora evolved in the analyzed period; however, Heliconia psittacorum had a low adaptation to the wetland system implanted (Figure 11).
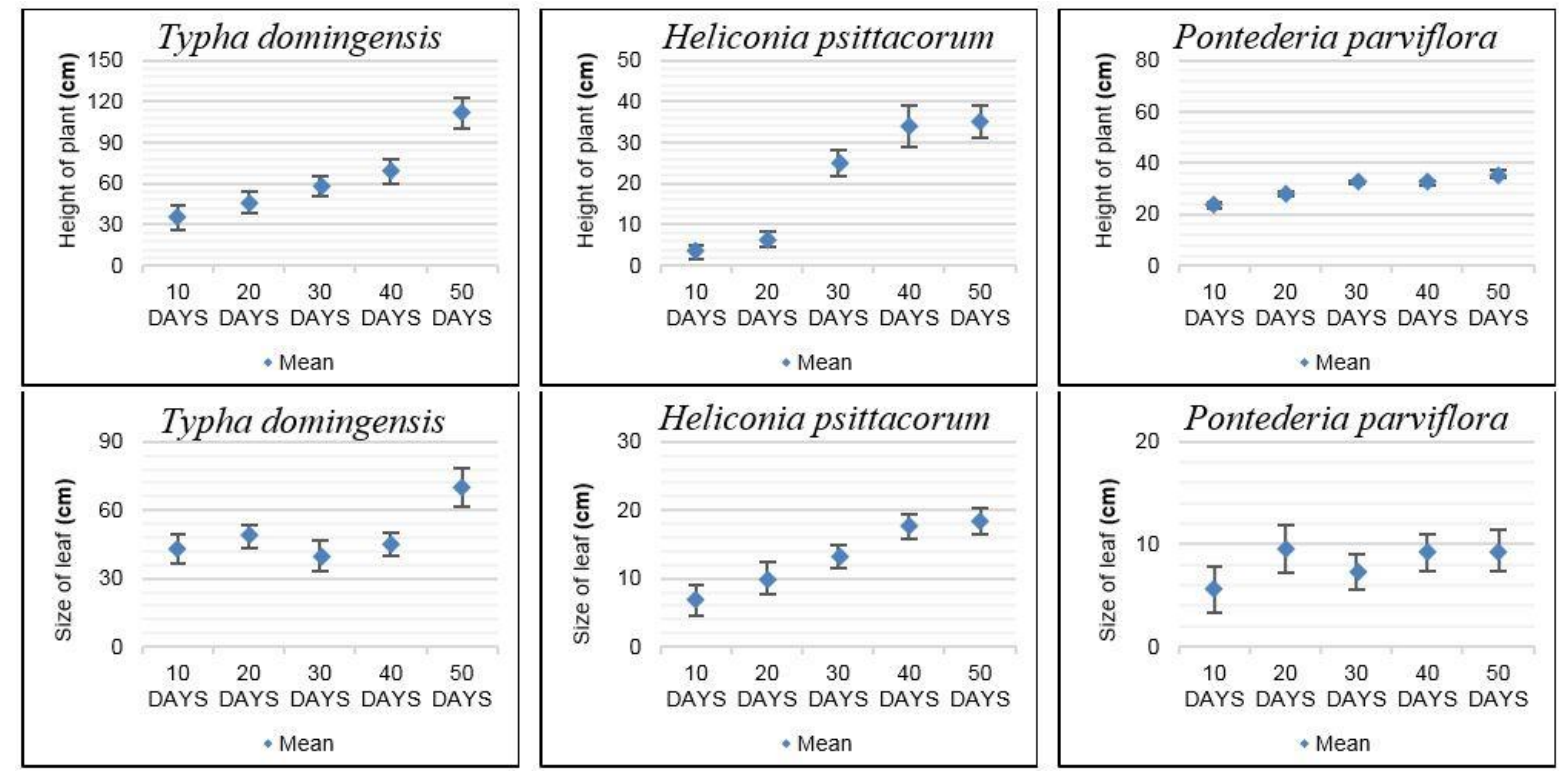

Figure 11. Total Nitrogen Removal.

The average height of the Typha domingensis plant in October 2017 was $35.2 \mathrm{~cm}$, and in February 2018 it had an average size of $111.2 \mathrm{~cm}$. In addition, Heliconia psittacorum obtained an average height in October 2017 of $3.36 \mathrm{~cm}$, and in February 2018 it was $35.2 \mathrm{~cm}$. The Pontederia parviflora species reached $23.55 \mathrm{~cm}$ at the beginning of the period, and at the end $35.6 \mathrm{~cm}$ (Figure 12). 


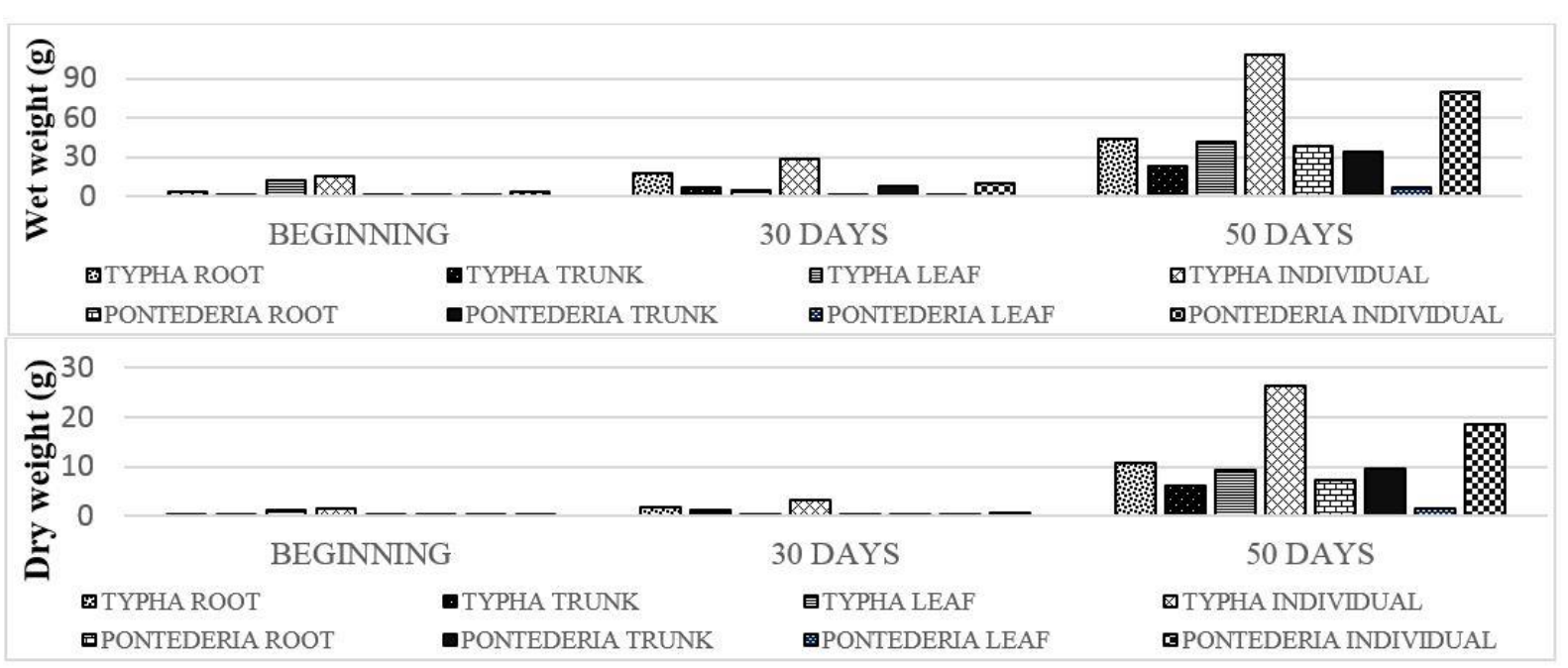

Figure 12. Macrophyte growth.

The mean growth of the leaf of the Typha domingensis species was initially $43.05 \mathrm{~cm}$, reaching $72.02 \mathrm{~cm}$; compared to Lorenzen et al. (2001), Typha domingensis had similar growth, and in its experiment the final size was $97 \mathrm{~cm}$. On the other hand, the species Heliconia psittacorum had an average increase of $6.74 \mathrm{~cm}$, and at the end of the studied period reached $18.40 \mathrm{~cm}$, compared to Cerqueira et al. (2008). These species showed considerable development, since species presented average growth of $97.1 \mathrm{~cm}$. The average leaf length of the Pontederia parviflora started at 5.70 and ended at $9.45 \mathrm{~cm}$. The biomass growth was measured in the Typha domingensis and Pontederia parviflora species, comparing the beginning and end period of 50 days. In the first plant there was an individual increase in its wet weight of $92.53 \mathrm{~g}$ and in the dry weight of $24.60 \mathrm{~g}$, compared to the second. Regarding the Pontederia parviflora species, the individual wet weight was $76.36 \mathrm{~g}$ and the dry weight was $18.15 \mathrm{~g}$. In this plant biomass analysis, we were not able to determine the weight of the Heliconia psittacorum.

\subsection{Statistical Analysis}

The static ANOVA test was performed for 5 and 10 days of HDT, with a significance of $5 \%$ for all parameters. The COD, $\mathrm{SO}_{4}$ and TDS, both for 10 days of HDT, were significant at $10 \%$, according to ANOVA.

\section{CONCLUSION}

To sum up the experiment, it was concluded that the wetlands present a greater concentration removal in the CWs (TCW, HCW and PCW) than in the non-planted ones. Among those planted, PCW was the one that most stood out in the removal of organic matter and macronutrients. It was the $\mathrm{CW}$ that obtained the highest result in 7 of the analyzed parameters in the HDTs of 5 days and 10 days.

Plant growth was fast, as the Typha domingensis and Pontederia parviflora species flowered at the end of five months, and also multiplied in individuals. However, Heliconia psittacorum showed a slower evolution with little productive adaptation.

The parameters such as $\mathrm{COD}, \mathrm{SO}_{4}$ and TDS had a significance of 5\% in the ANOVA test, proving that HDT in the $\mathrm{CW}$ can be efficient in the removal of these pollutants even with the variation of the input load.

\section{IPABH}

Rev. Ambient. Água vol. 14 n. 4, e2335 - Taubaté 2019 


\section{REFERENCES}

ABOU-ELELA, S. I.; HELLAL, M. S. Municipal wastewater treatment using vertical flow constructed wetlands planted with Canna, Phragmites and Cyprus. Ecological Engineering, v. 47, p. 209-213, 2012. https://doi.org/10.1016/j.ecoleng.2012.06.044

ANSOLA, G. et al. Experimental and full-scale pilot plant constructed wetlands for municipal wastewaters treatment. Ecological Engineering, v. 21, p. 43-52, 2003. https://doi.org/10.1016/j.ecoleng.2003.08.002

CASAS-LEDÓN, Y. et al. Life-cycle greenhouse gas emissions assessment and extended exergy accounting of a horizontal-flow constructed wetland for municipal wastewater treatment: A Case Study in Chile. Ecological Indicators, v. 74, p. 130-139, 2017. https://doi.org/10.1016/j.ecolind.2016.11.014

CASELLES-OSORIO, A. et al. Efficiency of Mesocosm-Scale Constructed Wetland Systems for Treatment of Sanitary Wastewater Under Tropical Conditions. Water Air Soil Pollut, v. 220, p. 161-171, 2011. https://doi.org/10.1007/s11270-011-0743-7

CASELLES-OSORIO, A. et al. Horizontal subsurface-flow constructed wetland removal efficiency using Cyperusarticulatus L. Ecological Engineering, v. 99, p. 479-485, 2017. https://doi.org/10.1016/j.ecoleng.2016.11.062

CERQUEIRA, L. L. et al. Desenvolvimento de Heliconia psittacorum e Gladiolus hortulanus irrigados com águas residuais tratadas. Revista Brasileira de Engenharia Agrícola e Ambiental, p. 606-613, 2008.

CHERNICHARO, C. A. D. L. Reator anaeróbios. 2. ed. Belo Horizonte: Editora UFMG, 2019.

EBRAHIMI, A. et al. Efficiency of Constructed Wetland Vegetated with Cyperus alternifolius Applied for Municipal Wastewater Treatment. Hindawi Publishing Corporation Journal of Environmental and Public Health, v. 2013, 2013. http://dx.doi.org/10.1155/2013/815962

FREITAS, G. P. D. et al. Sistema de tratamento de efluentes para o campus da Universidade Federal de Campina Grande na cidade de Pombal. Revista Verde de Agroecologia e Desenvolvimento Sustentável, v. 11, n. 2, p. 08-12, 2016.

HSU, C.-B. et al. Biodiversity of constructed wetlands for wastewater treatment. Ecological Engineering, v. 37, p. 1533-1545, 2011. https://doi.org/10.1016/j.ecoleng.2011.06.002

INMET. Banco de Dados Meteorológicos para Ensino e Pesquisa. 2018. Available at: http://www.inmet.gov.br/sonabra/pg_dspDadosCodigo_sim.php?QTkwMQ==. Access: 9 Mar. 2018.

KADLEC, R. H.; KNIGHT, R. L. Treatment Wetlands. Boca Raton: Lewis Publishes, 1996.

LETO, C. et al. Effects of plant species in a horizontal subsurface flow constructed wetland phytoremediation of treated urban wastewater with Cyperus alternifolius L. and Typha latifolia L. in the West of Sicily (Italy). Ecological Engineering, v. 61, p. 282-291, 2013. https://doi.org/10.1016/j.ecoleng.2013.09.014 
LI, X. et al. The Significance of Myriophyllum elatinoides for Swine Wastewater Treatment: Abundance and Community Structure of ammonia - Oxidizing Microorganisms in Sediments. Plos One, v. 10, n. 10, 2015. https://doi.org/10.1371/journal.pone.0139778

LORENZEN, B. et al. Growth, biomass allocation and nutrient use efficiency in Cladium Jamaicense and Typha domingensis as affected by phosphorus and oxygen availability. Aquatic Botany- Elsevier, v. 70, p. 117-133, 2001. https://doi.org/10.1016/S03043770(01)00155-3

MAINE, M. A. et al. Nutrient and metal removal in a constructed wetland for wastewater treatment from a metallurgic industry. Ecological Engineering, v. 26, p. 341-347, 2006. https://doi.org/10.1016/j.ecoleng.2005.12.004

MENESES, M. et al. Life Cycle Assessment as an environmental evaluation tool for control strategies in wastewater treatment plants. Journal of Cleaner Production, v. 107, n. 65, p. 653-661, 2015. https://doi.org/10.1016/j.jclepro.2015.05.057

MORRISON, M.; SRINIVASAN, R. S.; RIES, R. Complimentary life cycle assessment of wastewater treatment plants: An integrated approach to comprehensive upstream and downstream impact assessments and its extension to building-level wastewater generation. Sustainable Cities and Society, v. 23, p. 37-49, 2016. https://doi.org/10.1016/j.scs.2016.02.013

PELISSARI, C. et al. Nitrogen transformation in horizontal and vertical flow constructed wetlands applied for dairy cattle wastewater treatment in southern Brazil. Ecological Engineering, v. 73, p. 307-310, 2014. https://doi.org/10.1016/j.ecoleng.2014.09.085

RODRÍGUEZ, M.; BRISSON, J. Pollutant removal efficiency of native versus exotic common reed (Phragmitesaustralis) in North American treatment wetlands. Ecological Engineering, v. 74, p. 364-370, 2015. https://doi.org/10.1016/j.ecoleng.2014.11.005

SANTÍN, I. et al. Advanced decision control system for effluent violations removal in wastewater treatment plants. Control Engineering Practice, v. 49, p. 60-75, 2016. https://doi.org/10.1016/j.conengprac.2016.01.005

SEHAR, S. et al. A comparative study of macrophytes influence on wastewater treatment through subsurface flow hybrid constructed wetland. Ecological Engineering, v. 1, p. 62-69, 2014. https://doi.org/10.1016/j.ecoleng.2015.04.009

SEZERINO, P. H. et al. Experiências brasileiras com wetlands construídos aplicados ao tratamento de águas residuárias: parâmetros de projeto para sistemas horizontais. Engenharia Sanitária Ambiental, v. 20, n. 1, p. 151-158, 2015. https://dx.doi.org/10.1590/S1413-41522015020000096615

SOHSALAM, P.; ENGLANDE, A. J.; SIRIANUNTAPIBOON, S. Seafood wastewater treatment in constructed wetland: Tropical case. Bioresource Technology, v. 99, p. 12181224, 2008. https://doi.org/10.1016/j.biortech.2007.02.014

TOSCANO, A. et al. Comparison of removal efficiencies in Mediterranean pilot constructed wetlands vegetated with different plant species. Ecological Engineering, v. 75, p. 155160, 2015. https://doi.org/10.1016/j.ecoleng.2014.12.005

VERA, L.; MARTEL, G.; MÁRQUEZ, M. Two years monitoring of the natural system for wastewater reclamation in Santa Lucía, Gran Canaria Island. Ecological Engineering, v. 50, p. 21-30, 2013. https://doi.org/10.1016/j.ecoleng.2012.08.001 
VYMAZAL, J. Removal of nutrients in various types of constructed wetlands. Science of the $\begin{array}{llllll}\text { Total Environment, } & \text { v. } 380, & \text { p. } & 48-65, & \end{array}$ https://doi.org/10.1016/j.scitotenv.2006.09.014

WAGNER, J.; DA COSTA, R. H. R. Reator em bateladas sequenciais de grânulos aeróbios: estudo da formação dos grânulos e do efeito da duração do ciclo na remoção de carbono, nitrogênio e fósforo de esgoto doméstico. Engenharia Sanitária Ambiental, v. 20, n. 2, p. 269-278, 2015. https://dx.doi.org/10.1590/S1413-41522015020000078980 